\title{
Low Carbon Affordable Apartments in Hot-Humid Climate of Indonesia: Design Concept of the Full-Scale Experimental House
}

\author{
Fathina Izmi Nugrahanti \\ Department of Architecture \\ Institut Teknologi Bandung \\ Bandung, Indonesia \\ fathinaizmi@gmail.com \\ Tetsu Kubota \\ Graduate School for International \\ Development and Cooperation \\ Hiroshima University \\ Hiroshima, Japan \\ tetsu@hiroshima-u.ac.jp
}

\author{
Dewi Larasati \\ Department of Architecture \\ Institut Teknologi Bandung \\ Bandung, Indonesia \\ Dewizr_ar@yahoo.com
Andhang Rakhmat Trihamdani $R \& D$ Center
PT. YKK AP Indonesia
Tangerang, Indonesia
andhang-rt@ykkap.co.id

\author{
Kouhei Morita \\ Value Verification Center (VVC) \\ YKK AP Inc. \\ Japan \\ Hirofumi Inoue \\ Value Verification Center (VVC) \\ YKK AP Inc. \\ Japan
}

\begin{abstract}
In Indonesia, GHG emissions are expected to increase up to $1,751 \mathrm{MtCO2e}$ in 2030 . In parallel, as a response towards the Paris Agreement, the Indonesian government has made a commitment through NDC to reduce the carbon emissions by 2030. On the other hand, the Indonesian population continues to increase, leading to the issue of housing backlog. Accordingly, the government released a nationwide project "Program Sejuta Rumah" in 2015 to provide affordable houses wherein will inevitably arise the carbon emission. A mid-rise apartment is constructed in Tegal as a full-scale experimental house to propose a new standard type of lowcarbon affordable apartment as a solution for future Indonesian housing. This paper describes the design concept of the proposed low-carbon apartment based on the results of several fundamental studies, including a typological study of existing apartments, local weather analysis, and CFD simulation. This research found some interesting design concept such as the effectiveness of vertical narrow-closed atrium, the performance of wind fin, and the potential of wind catcher. Those results will be proven further experimentally in this real scale project.
\end{abstract}

Keywords; low-carbon, energy-saving, thermal comfort, apartment

\section{INTRODUCTION}

As the most energy consumptive country in Southeast Asia, Indonesia's energy demand will continue to increase along with the economic growth (GDP) and population growth $(6.04 \%$ and $0.71 \%$ per year respectively). This resulted in the growth of final energy demand by $5.3 \%$ per year, which is expected to reach 4,569 million BOE in 2050 [1][2]. In line with that, Indonesia's greenhouse gas (GHG) emissions are also projected to increase to 2,869 million tons of $\mathrm{CO}_{2} \mathrm{e}$ in 2050 , giving a ratio of growth at $4.9 \%$ per year [3].

Moreover, the percentage of people living in urban areas are predicted to increase from $49.8 \%$ in 2010 to $66.6 \%$ in 2035, reaching around 305 million in 2035, in which middle-class will dominate the population distribution. The middle-class is expected to reach 200 million people by 2045, as reported by the Minister of National Development [4]. As a result, an enormous housing backlog problem is now reported by the Indonesian Central Bureau of Statistics (BPS) in 2016, reaching 11.56 million shortages nationwide [5]. In order to combat such shortages, the Indonesian government released a nationwide project to provide affordable houses in 2015, which is the so-called "Program Sejuta Rumah". Unfortunately, the project has yet to be implemented as smooth as originally planned.

It has been reported that the above-mentioned massive housing provisions do not meet the inhabitants' needs, especially in high-rise housing [6]. The housing design was more or less copied from the European standard apartments in which socio-cultural and local environment were not taken into account [7]. Kisnarini [6] found that in terms of functionality, except for the balcony, the indoor spaces (e.g., bedroom, living room, kitchen, etc.) fell significantly behind the national standards, meeting only $50-55 \%$ of the needs. Furthermore, the average unit area surveyed $\left(23.14 \mathrm{~m}^{2}\right)$ was originally less than the national standard $\left(29.76 \mathrm{~m}^{2}\right)$, and thus the actual living spaces were extended up to $48.41 \mathrm{~m}^{2}$ by occupying the corridor (communal) space, which shows the lack of adaptability in the existing apartment units.

Moreover, the thermal conditions of existing apartments were found to be unsatisfactory due to the lack of ventilation strategies, shading, problematic building orientation, and poor / no insulation / thermal buffer zones, resulting in poor indoor air quality (IAQ) that can lead to the problem of sick building syndrome (SBS) [8]. In consequence, more occupants depend on air conditioning to achieve the desirable indoor thermal condition.

As reported in IEO [2], housing has become the third most energy-consuming sector in Indonesia. In 2050, $70 \%$ of energy in households will be provided by electricity and used mostly for air-conditioning, which will also impact the increase of GHG emissions. Therefore, it is important to provide the rapidly growing middle-class people with lowcarbon housing in the immediate future. The Indonesian government has made a commitment through NDC (nationally determined contributions) to reduce the GHG emissions by $29 \%$ (unconditional) or $41 \%$ (conditional) against BAU scenario by 2030 , in response to the Paris Agreement. 
power law curve with a power index of 0.28. Parametric analysis was employed in two phases. The simulation conditions are summarized in Table 1 and Fig. 1.

Table 1 Simulation setting land owned by the Tegal Authority since March 2019 to January 2020. This project aims to propose a new standard type of low-carbon affordable apartment for future Indonesia towards Paris Agreement. Tegal is known as a coastal town which has sufficient winds with hot weather. This experimental house, in collaboration with Puslitbangkim PU, is designed to represent high-rise owned apartments (Rusunami type) in Indonesia. This paper explains the design concept of the Tegal experimental house based on the results of several fundamental studies.

\section{Methodology}

This research uses experimental approach which output, the design, was based on the results of several fundamental studies. Since the aim is to proposed a new standard type of low-carbon affordable apartment, some studies were done beforehand. First, to formulate a suitable design for the future Indonesian apartment, understanding the typology of existing rusunami is important. Second, analysis of the local weather condition is conducted to get a precise input parameter for the next phase, CFD simulation. Those results become the baseline design for the full-scale experimental house.

\section{A. Typology: Existing Rusunami Apartments}

The typology of existing high-rise apartments (i.e. Rusunami) was analyzed as a preliminary study. Internetbased data of Rusunami apartments including information about building's features in the apartments (e.g., corridor type, number of stories, etc.) were collected from three major cities in Indonesia, which are Jakarta, Bogor, Depok, Tangerang, Bekasi (Jabodetabek), Surabaya, and Bandung. The obtained data were analyzed to determine the typical design and configuration of apartments as well as its unit types.

In total, 66 apartments were surveyed. The total samples cover 202 of apartment units, which consist of 77 units of studio type, 40 units of 1 bedroom type, 100 units of 2 bedroom type, 17 units of 3 bedroom type, 14 units of loft type, and 4 units of an apartment with maid room. This analysis focuses on middle-class apartments and does not include luxurious apartments.

\section{B. Site Analysis: Local Weather Conditions in Tegal}

Weather conditions in Tegal were analyzed to examine the possible passive cooling techniques suitable for the experimental house. The standard weather data from ASHRAE (i.e. IWEC2) were analyzed. IWEC2 (International Weather for Energy Calculation ver.2) provides the typical weather files suitable for use in building energy simulation program [9]. The data were derived from the ground observation stations measuring wind speed and direction, cloud cover, dry-bulb temperature, dew-point temperature, relative humidity, rainfall, etc. for at least 12 years up to 25 years until 2008.CFD Simulation: Ventilation Strategy

\section{CFD Simulation: Ventilation Strategy}

CFD analysis using STREAM V13 was conducted to determine the basic concept of ventilation strategy for the experimental house, where vertical wind profile was set to be

\begin{tabular}{|l|l|}
\hline \multicolumn{1}{|c|}{ Parameter } & \multicolumn{1}{c|}{ Condition } \\
\hline Scenario & 5 Pattern \\
\hline Wind velocity & $\mathrm{V}_{\mathrm{B}}: 2.0 \mathrm{~m} / \mathrm{s}$ (Dry season) \\
& $\mathrm{V}_{\mathrm{B}}: 2.3 \mathrm{~m} / \mathrm{s}$ (Wet season) \\
\hline Wind Direction & Front, side, oblique (diagonal) \\
\hline Model & k- $\varepsilon$ turbulence model \\
\hline
\end{tabular}

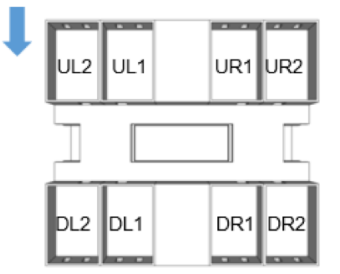

$\mathrm{U}:$ Windward rooms L-R : Left - Right Numbered from centre

Fig. 1 Room labeling system

Phase 1 investigates the effect of the void space on natural proposed, namely Case 1 (apartment with horizontal void space), Case 2 (apartment with vertical void space), and Case 3 (apartment without void space). The best result from Phase 1 was then investigated further in Phase 2. Phase 2 focuses more on the design techniques to further improve the performance of the void space (e.g., wind fin, void space dimension, vertical fin, etc.). Thermal analysis was not involved in this parametric study.

\section{RESULTS AND DISCUSSION}

\section{A. Typology: Existing Rusunami Apartments \\ 1) Building configuration} surveyed are categorized as a single-core building type where the core is located on one side of the building (Fig. 2). double-loaded type, where the rows of apartment units are located on both sides of the corridor. It is understandable since more economical in the business perspective. However, those double-loaded apartments may cause several environmental problems such as poor cross-ventilation and lack of daylighting because each of the units cannot secure windows on both the exterior wall and its opposing corridor side.
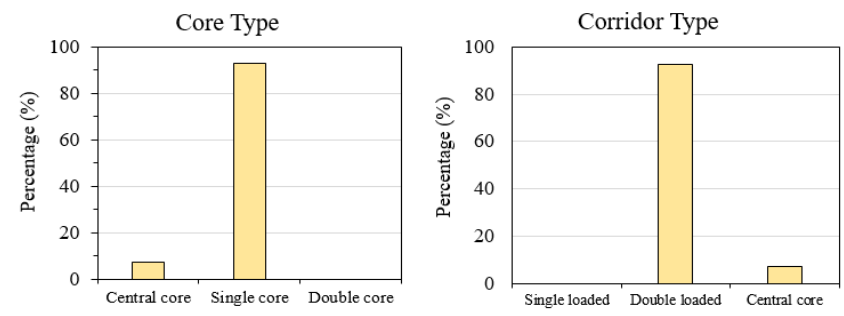

Fig. 2 Core type and corridor type if existing apartments

\section{Room labelling system} $\mathrm{D}$ : Downwind rooms ventilation performance. Three baseline designs were

The results showed that more than $90 \%$ of apartments Similarly, approximately $90 \%$ of them are categorized as a a single core and double-loaded corridor is very efficient and 
The further results indicated that there are lots of building configuration types for apartments, but the most common types are found to be U-, L-, and I- shape (Fig. 3). Meanwhile, as for the number of floors, it varies from 10 to above 35 stories with an average of 21-story excluding the service floors (for a lobby, M/E, car park, public facilities, etc.). This variation is strongly influenced by the building regulation that limits the floor area ratio in respective areas.

As a result, it was found that a single core type with an Ishape building was considered to be one of the most common types of existing Rusunami apartments, and it was adopted as a default form in the experimental house design.

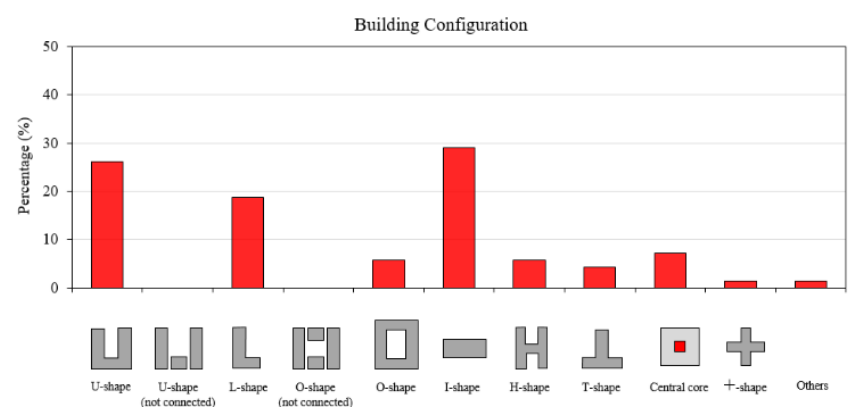

Fig. 3 Building configuration of existing apartment

\section{2) Unit Configuration}

The results showed that among 202 apartment units surveyed, there are 5 common types of apartment units, i.e. studio, 1BR, 2BR, 3BR, and loft. Those have an average area of $25.3 \mathrm{~m}^{2}, 34.04 \mathrm{~m}^{2}, 44.9 \mathrm{~m}^{2}, 65.6 \mathrm{~m}^{2}$, and $95.3 \mathrm{~m}^{2}$, respectively (Fig. 4). The most common types are found to be studio and 2BR type. The studio unit normally accommodates 2 persons (single or couple) while $2 \mathrm{BR}$ is for up to 4 persons (family). The national standard sets $30 \mathrm{~m}^{2}$ as the maximum floor area for the 2BR unit, which is far smaller than the actual average floor areas for $2 \mathrm{BR}$ units that we found in this research $\left(44.9 \mathrm{~m}^{2}\right)$.

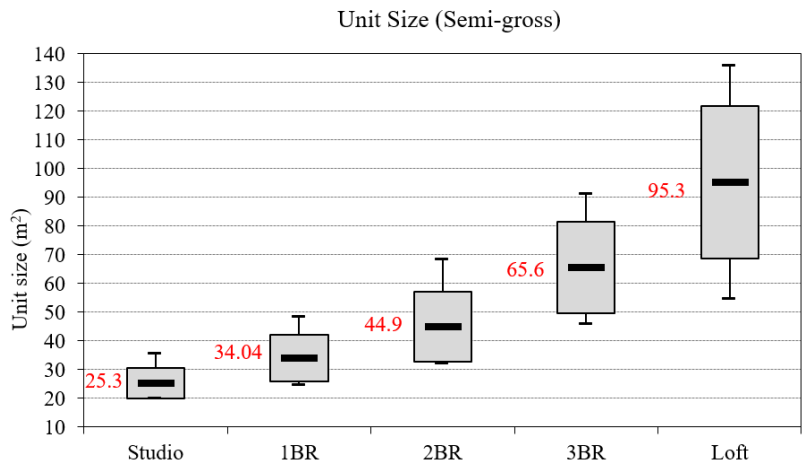

Fig. 4 Unit size for existing unit types

This survey also revealed the common location for the bathroom and the size of the balcony in the units. As shown, most units have its bathroom on the corridor side (78\%) since it is more convenient and easier for maintenance. Meanwhile, most units have a half-size balcony as illustrated in Fig. 5.

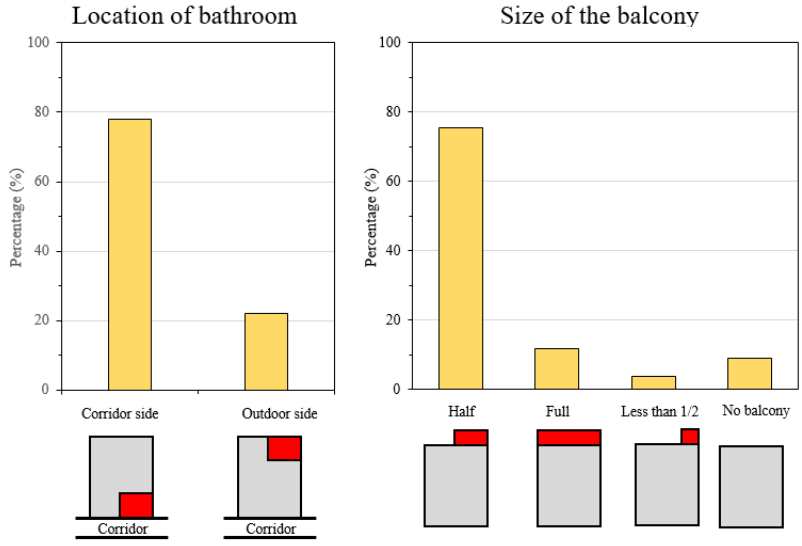

Fig. 5 Location of bathroom and balcony size of existing units

\section{B. Site Analysis: Local Weather Conditions in Tegal}

We investigated the weather pattern of Tegal town based on the analysis of IWEC2 weather data. November was found to be the hottest month during the period with an average temperature of $28.4^{\circ} \mathrm{C}$, while February recorded the minimum monthly average temperature of $26.1^{\circ} \mathrm{C}$ (Fig. 6).

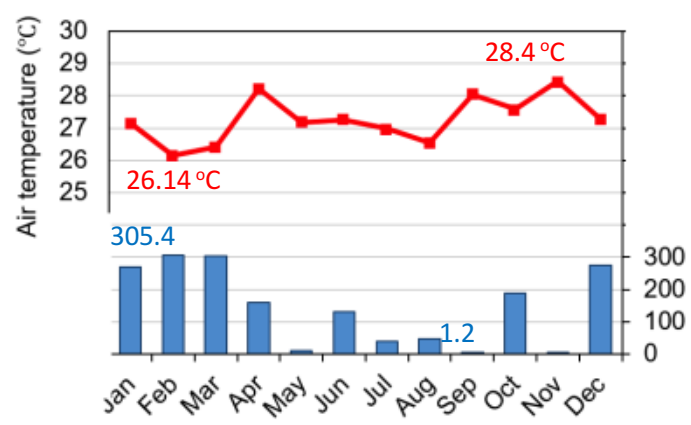

Fig. 6 Tegal weather condition

According to the results of wind analysis, in Tegal, a year can be divided into the following two periods: dry season (April to December) and wet season (January to March). The wind patterns of the two seasons are illustrated in Fig. 7. From the windrose and sun path diagram analysis, it is found that the optimum orientation for mid-to-high-rise apartments in this site is in 22.5 degrees from North (i.e. either one of the unit's facade faces NNE). In that case, the buildings can receive the seasonal winds from the front and rear side of the building at right angles at least during the dry season, while minimizing the heat gain from the direct solar radiation. 
for the leeward units, obtain low values and the resulting

\section{Dry season: Apr to Dec}
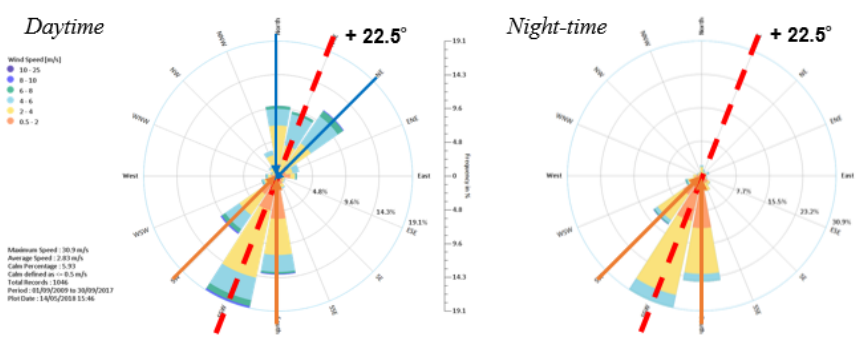

Wet season: Jan to Mar
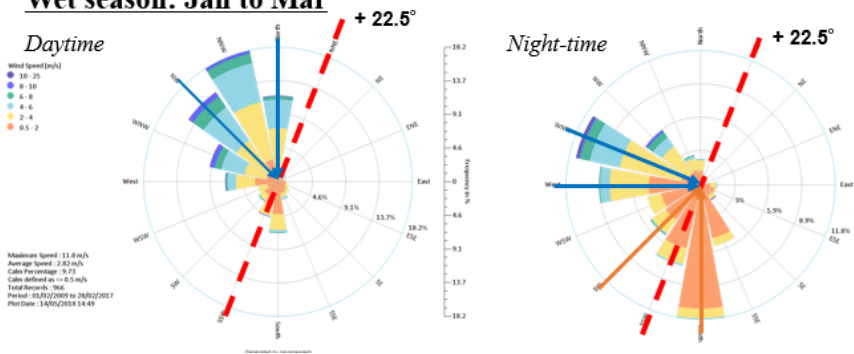

Fig. 7 Windrose of the dry and wet season in Tegal

\section{CFD Simulation: Ventilation Strategy}

\section{1) Phase 1}

In Phase 1, 3 void types are investigated to understand the resulting ventilation performances of the units. Fig. 8 shows the wind velocities (inflow is $2 \mathrm{~m} / \mathrm{s}$ at the building height) and the resultant ventilation volumes $\left(\mathrm{m}^{3} / \mathrm{s}\right)$ of the units in three cases when the wind direction is at right angle from the north.

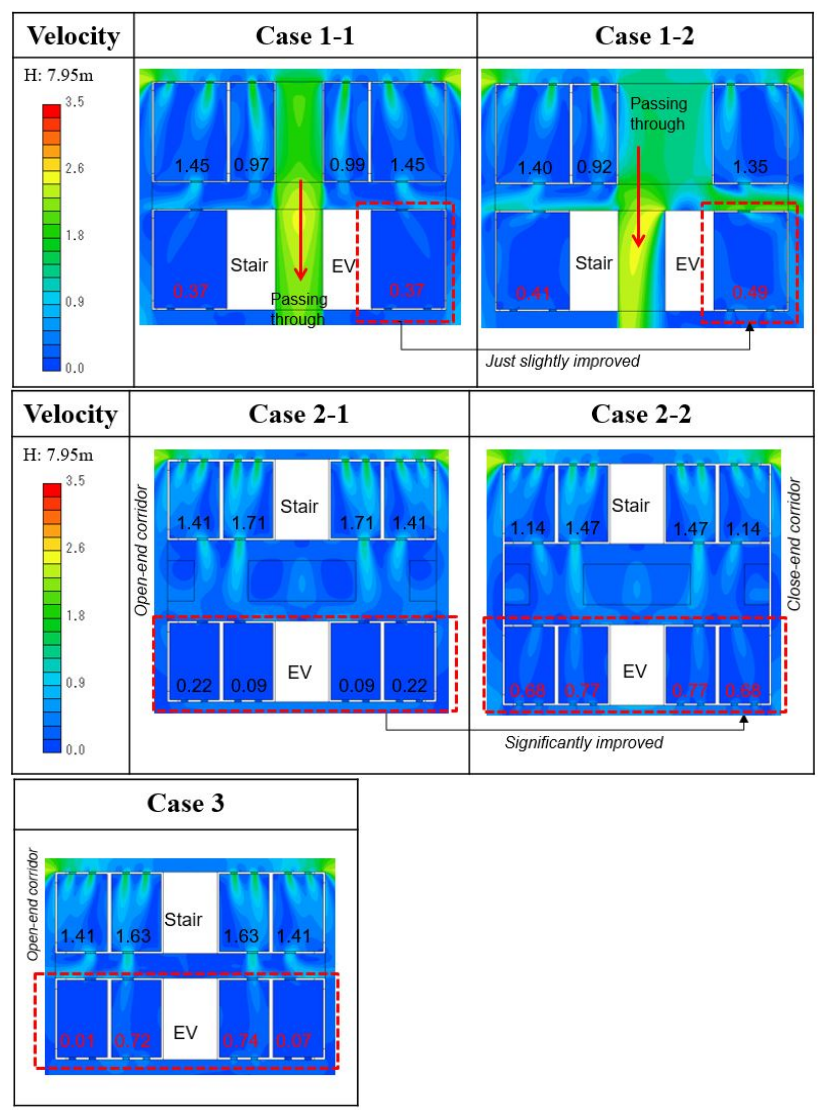

Fig. 8 Velocity contour plot for phase 1

As expected, in Case 3, where there is no void with an open-end corridor, the velocities inside the units, especially ventilation volumes range from $0.01-0.74 \mathrm{~m}^{3} / \mathrm{s}$ in the leeward units. In Case 1, where a horizontal void space is designed, winds pass through the void spaces but this does not contribute to increasing the ventilation rates for the surrounding units. The resulting ventilation volumes are approximately 0.3 $00000000000.5 \mathrm{~m}^{3} / \mathrm{s}$ in the leeward units.

In contrast, in Case 2, where the vertical void spaces are designed, the indoor velocities are increased compared with the other types. It should be noted that when the roof and side walls are closed such as Case 2-2, indoor velocities and resulting ventilation volumes are well improved even in the leeward side of the building. The resulting ventilation volumes are approximately $0.7-0.8 \mathrm{~m}^{3} / \mathrm{s}$ in the leeward units. This is probably because the air pressure inside the void space was increased due to the inflow from the pilotis on the ground floor. The increased air pressure probably increased the air pressures on the walls of the leeward units and generated crossventilation for the units.

\section{2) Phase 2}

\section{- Void width}

We selected Case 2-2 design (vertical closed void) for the following analysis. First, the effect of void width on ventilation rates is studied. The width varies from $1.5 \mathrm{~m}, 3 \mathrm{~m}$, to $4.5 \mathrm{~m}$ wide. Fig. 9 illustrates the velocities and resulting ventilation volumes in the units under the three different wind directions. As shown, higher wind velocities are obtained when the building received the winds from the front side at right angle even in the leeward units. The smaller the void width is, the larger the ventilation volume would be. In the case of void width of $1.5 \mathrm{~m}$, the resulting ventilation volumes range from $1.7-2.2 \mathrm{~m}^{3} / \mathrm{s}$ in the windward units, whereas the corresponding volumes are about $1.0 \mathrm{~m}^{3} / \mathrm{s}$ in the leeward units. For this front wind, it was also found that velocities in the leeward units on the bottom corners of right and left can still be improved by adding a window to the right and left side of the building.

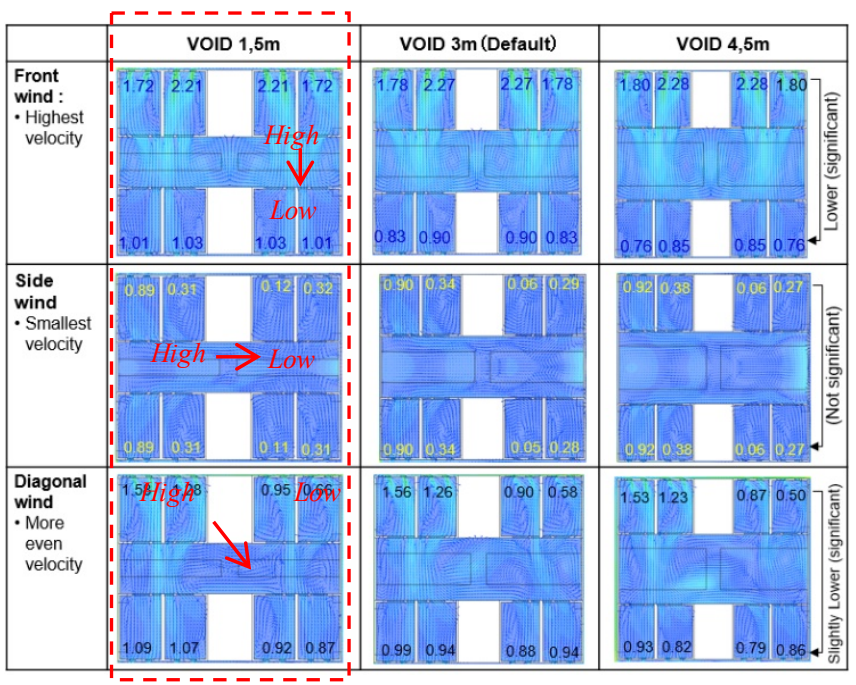

Fig. 9 Velocity contour plot for the void width effect

On the contrary, when the wind direction is from the side of the building, indoor wind velocities and the resulting ventilation volumes obtain the lowest values among three wind directions. Meanwhile, as for the diagonal/oblique wind 
direction, the lower velocities are seen on the right side of the building, but overall ventilation volumes are still around 0.5$0.9 \mathrm{~m}^{3} / \mathrm{s}$. This wind direction also gives relatively equally distributed air velocities throughout the rooms, although the ventilation volumes are relatively lower than those with the front winds. Just like the front wind, the case of diagonal wind also indicates the same pattern of void width effect in which larger void width results in lower ventilation volumes for the units. Narrower void width such as $1.5 \mathrm{~m}$ width, is, therefore, a better option.

\section{- Wind fin}

Second, the effect of vertical wind fin is investigated. This vertical fin is intended to further increase the air pressure near the fin to generate upward winds towards the void space. This scenario will be functional during the dry season where wind dominantly comes from the front and diagonal directions. Only the models with void width of $1.5 \mathrm{~m}$ and $4.5 \mathrm{~m}$ are taken into account, and we put the different sizes of wind fin $(0.75$ $\mathrm{m}$ and $2.25 \mathrm{~m}$ respectively) at the bottom of the void space.

In the case of front wind, the results proved that the installation of wind fin increases the ventilation volumes in both windward and leeward sides of the building, spreading the air velocities more evenly. Further results show that in the case of front wind, upward winds are generated near the edges of the building, while the downward winds can be seen near the center (Fig. 10).

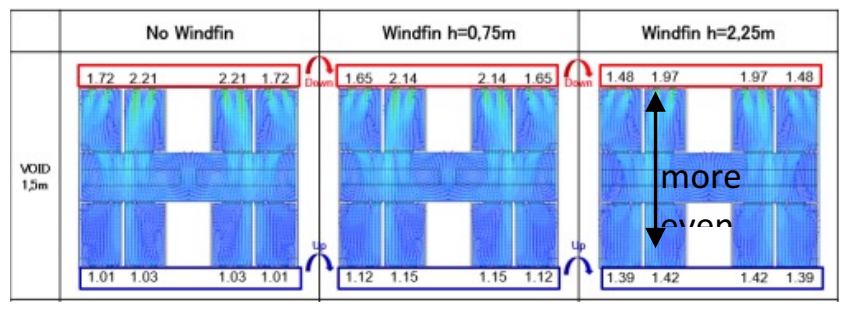

Fig. 10 Velocity contour plot for the vertical wind fin effect

In conclusion, wind fin can increase the air pressure inside the vertical void, and therefore improve the cross-ventilation even in the leeward side of the building. In the case of front wind, narrower void with larger wind fin will induce better ventilation rates. On the contrary, when the diagonal wind comes, a shorter (or not at all) wind fin will give a better result. Therefore, the wind fin design should be adjusted, depending on the wind direction.

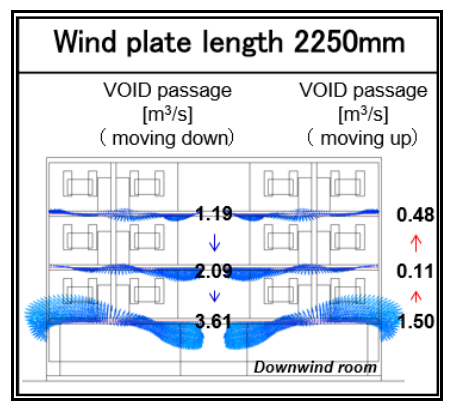

Fig. 11 Velocity vector passing through each floor void

\section{- Windcatcher}

Third, in the case of side wind, the effect of windcatcher is studied. During the rainy season, winds come mostly from the side and diagonal directions, an additional device is needed to catch the side wind, obstructing the wind so it will come inside the units. Thus, a windcatcher installed beside the window is taken into account. As shown in Fig. 12, the results show that the larger the windcatcher is, the better airflow will be directed into the units. But in reality, a long windcatcher on the narrow corridor is not practical since it will disturb the pedestrians, therefore we should carefully design the wind catchers.

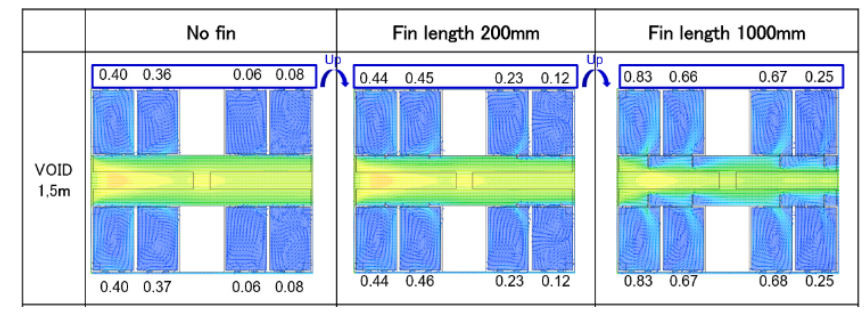

Fig. 12 Velocity contour plot for the windcatcher effect

\section{Other Design Features}

Besides the features mentioned before, some active and passive design strategies are also adopted in the experimental house. PCM or phase change material has a great potential in reducing fluctuations of indoor temperatures in buildings, as well as offering thermal storage effects. Lin et al. [10] studied the application of shape-stabilized PCM panels in buildings as thermal energy storage. The results of simulation proved that by installing PCM under the floor, it can improve the indoor thermal comfort and eliminate approximately $47 \%$ of normal and peak hour energy use. Other research conducted by Kuznik and Virgone [11] was a full-scale experiment of PCM, using a thermal guard and climate chamber. It was discovered that PCM filled walls successfully reduced the overheating effects of the room and the surface temperature.

In the present experimental house, PCM will be installed below the floor structure to reinforce the structural cooling effect. Furthermore, exhaust fans will be installed on the upper ceiling area to increase the wind speeds near the PCMs to effectively increase the convectional heat transfer. Then, roof insulation, the external wall outer insulation, the external shading, will also be installed in the Tegal experimental house.

\section{Design of Tegal Experimental House}

The Tegal experimental house is designed based on the results of the above-mentioned fundamental studies (Fig. 13). Based on the typology study, a single core with an I-shape building is applied as a default building form. However, such a double-loaded apartment was found to be insufficient in cross-ventilation particularly on the leeward side of the building, and therefore an internal void space equipped with a vertical wind fin is designed to drive the prevailing winds moving upward in the daytime to achieve a well-distributed cross-ventilation for all the units (Fig. 14). Meanwhile, for the night-time, an exhaust fan (outlet) and louver (inlet) are installed on the ceiling to effectively cool the floor structure with phase change materials (PCMs). 


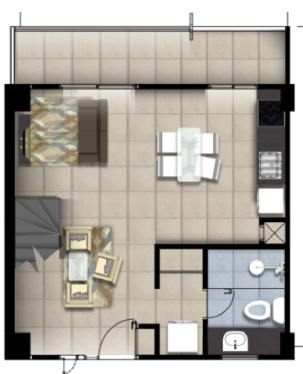

(a)

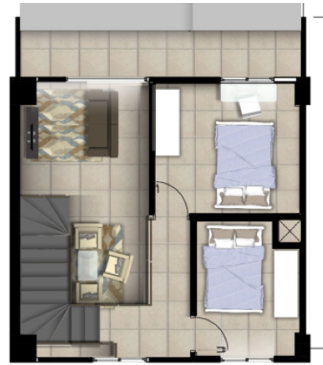

(b)

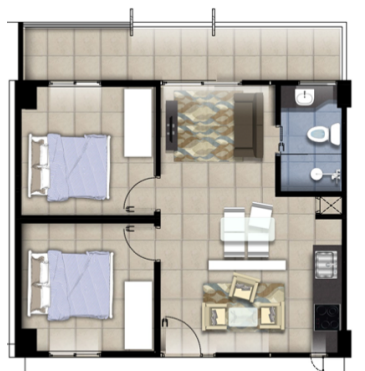

(c)

Fig. 15 Floor plan (a) 1st floor Loft, (b) Mezzanine Loft, (c) 2BR unit

In the unit, there are some features applied, i.e. insulation, exhaust fan and louver, PCM, sun shading, and reflective paint (Fig. 16). Based on the previous research [12], thermal insulation on the wall and ceiling is effective to prevent heat from transferring to indoor spaces. Moreover, exhaust fan and louver are installed on the upper ceiling to optimize forcednight ventilation that will cool the PCM below the floor slab. In the day time, radiative cooling will occur, thanks to the cooled PCM below the floor slab. In order to prevent solar radiation, a sun shading is installed on the balcony as well as a reflective paint painted on the outside of every unit and the rooftop.

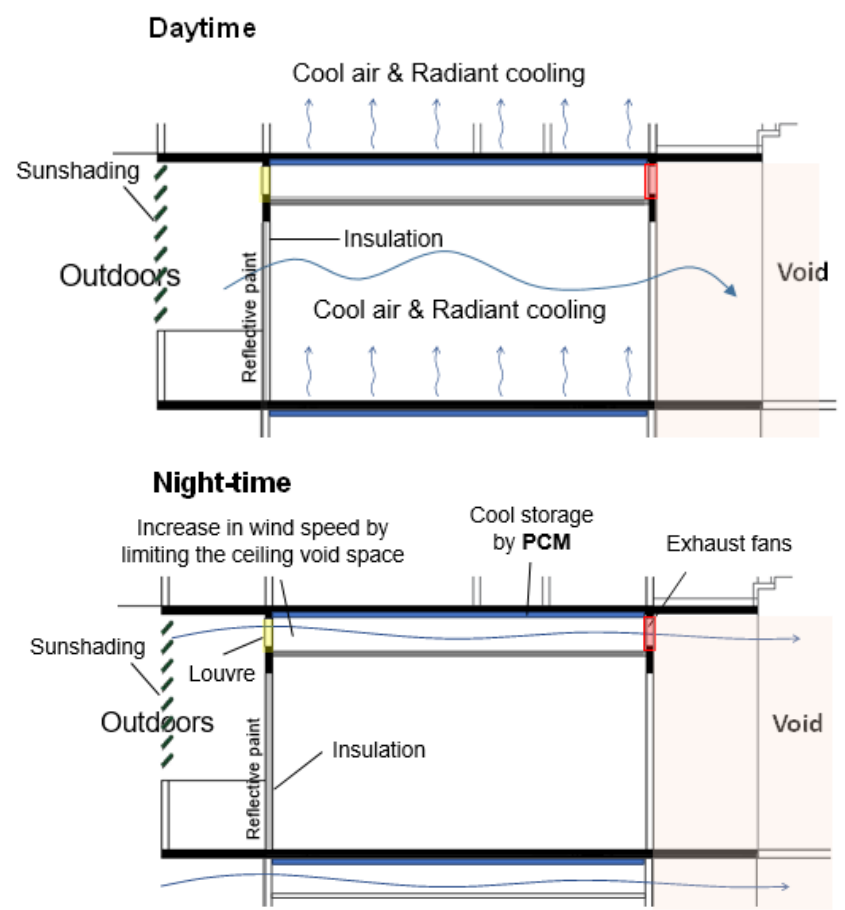

Fig. 16 Features and ventilation principles of the unit 


\section{CONCLUSIONS}

Many apartments in Indonesia nowadays do not meet the inhabitants' requirements, in terms of functionality and also thermal comfort. Therefore, we propose a new standard affordable apartment prototype for achieving thermal comfort as well as low-carbon for the future of Indonesia.

From the CFD simulation, it is found that vertical void would induce natural ventilation inside the units. The narrow void with close-end corridor will further give a better ventilation rate. Vertical wind fin on the ground floor managed to improve and distribute the airflow more evenly, especially in the dry season. The length of the fin needs to be adjustable so it can be changed according to the current weather conditions. Moreover, to catch the side and diagonal winds in the wet season, a windcatcher installed around the window is effective to direct the airflow into the units. The longer windcatcher the better, but the implementation has to be carefully considered since it can disturb the connectivity in the corridor.

There are also some other passive design principles that will be applied in this project based on some previous/ongoing studies. Since this research chooses experimental approach, these principles will be further investigated in the full-scale building to confirm their effectiveness in achieving a low-carbon apartment.

\section{ACKNOWLEDGMENT}

This research is a joint research between Hiroshima University as the leader and Puslitbangkim PU, supported by the grants from YKKAP Inc. and Nichias Corporation. The construction of the experimental house was conducted by LAPI Institut Teknologi Bandung (ITB).

\section{REFERENCES}

[1] R. Kisnarini, J. Post, E. van E. de W. de Ligny, and M. Mohammadi, "Providing adaptability of space to ensure sustainable living in lowcost housing in Indonesia," Procedia - Sos. Behav. Sci., vol. 179, pp. 222-229, 2015.

[2] BPPT, “Energi Outlook Indonesia 2018,” 2018.

[3] C. Transparency, "Brown to Green Report 2018: Indonesia," 2018.

[4] S. F. Laucereno, "Penduduk Kelas Menengah RI Diprediksi Tembus 200 Juta Jiwa di 2045," 2017. [Online]. Available: https://finance.detik.com/berita-ekonomi-bisnis/d-

3658580/penduduk-kelas-menengah-ri-diprediksi-tembus-200-jutajiwa-di-2045. [Accessed: 30-Jul-2019].

[5] SMF Indonesia, "SMF Highlight," 2017.

[6] R. Kisnarini, "Functionality and adaptability of low-cost apartment space design : a case of Surabaya Indonesia," Technische Universiteit Eindhoven, 2015.

[7] UNHABITAT, The Challenge of Slums - Global Report on Human Settlements. 2003.

[8] M. Nur and F. Alfata, "Fundamental Study on Indoor Thermal Environments in High-Rise Apartments in Hot-Humid Climates of Indonesia," 2018.

[9] ASHRAE, "International Weather for Energy Calculations, v 2.0," 2018.

[10] K. Lin, Y. Zhang, X. Xu, and H. Di, "Experimental study of underfloor electric heating system with shape-stabilized PCM plates," vol. 37, pp. 215-220, 2005.

[11] F. Kuznik, J. Virgone, and J. Noel, "Optimization of a Phase Change Material Wallboard for Building Use," Appl. Therm. Eng., vol. 28, no. 11-12, p. 1291, 2008.

[12] T. Kubota, M. A. Zakaria, M. H. Ahmad, and D. H. C. Toe, "EnergySaving Experimental House in Hot-Humid Climate of Malaysia," in Sustainable Houses and Living in the Hot-Humid Climates of Asia, $\mathrm{H}$. Takaguchi, Ed. Springer Nature Singapore Pte Ltd., 2018, pp. 457471 . 